\title{
Orvosok antibiotikumfelhasználással és -rezisztenciával kapcsolatos véleményének vizsgálata Magyarország délkeleti részén
}

\author{
Gajdács Márió dr. ${ }^{1}$ - Szabó Andrea dr. ${ }^{2}$ \\ Szegedi Tudományegyetem, Gyógyszerésztudományi Kar, Gyógyszerhatástani és Biofarmáciai Intézet, Szeged \\ ${ }^{2}$ Szegedi Tudományegyetem, Általános Orvostudományi Kar, Népegészségtani Intézet, Szeged
}

\begin{abstract}
Bevezetés: Antibiotikumok nélkül napjaink modern orvostudománya elképzelhetetlen lenne, az egyre terjedő rezisztencia azonban veszélyezteti hatékonyságukat.

Célkitüzés: Az orvosok antibiotikumfelhasználással és -rezisztenciával, illetve prevencióval és személyes felelősségtudattal kapcsolatos vélekedéseinek vizsgálata.

Módszer: Feltáró jellegú kvantitatív kérdőíves vizsgálat a Dél-Alföld régióban tevékenykedő ( $\mathrm{n}=105$ ) orvosok körében.

Eredmények: A válaszadók között kisebb arányban vannak azok, akik még nem ismerik fel az antibiotikumrezisztencia veszélyeit és saját szerepüket a megfelelő gyógyszerfelhasználás elősegítésében, emellett a döntő többség kiemelt szerepet tulajdonít a fertőző betegségekkel kapcsolatos megelőzésnek. A negatív gyakorlati attitûd hiányos ismeretekkel és nem megfeleló elméleti attitüddel párosult.

Következtetés: Az orvosok vélekedésében és attitűdjében heterogén eloszlást tapasztaltunk. A témával kapcsolatos folyamatos szakmai továbbképzés hosszú távon kiemelt jelentőségú.
\end{abstract}

Orv Hetil. 2020; 161(9): 330-339.

Kulcsszavak: antibiotikum, rezisztencia, vélekedés, attitúd, háziorvos

\section{Physicians' opinions towards antibiotic use and resistance in the southeastern region of Hungary}

Introduction: Without antibiotics, today's modern medicine would be unimaginable, but the emergence of antimicrobial resistance threatens their effectiveness.

Aim: The aim of this study was to investigate the knowledge and attitudes of general practitioners towards antibiotic use and resistance, prevention and their opinion on their personal liability related to these areas.

Method: An exploratory, quantitative study was carried out among physicians $(\mathrm{n}=105)$ working in the southeastern region of Hungary.

Results: Among the respondents, the ones who do not comprehend the severity of the issue of antibiotic resistance and their role in the prudent use of these drugs, are much fewer. The majority of the answerers attribute an important role to prevention in the fight against infectious disease. Negative practical attitude was found to be significantly correlated to gappy knowledge and improper theoretical attitude.

Conclusions: A heterogeneous dispersion in the general practitioners' attitudes was found. Continuous professional development (CPD) of general practitioners in the topic of antibiotic resistance could be of great importance.

Keywords: antibiotics, resistance, opinion, attitude, general practitioner

Gajdács M, Szabó A. [Physicians' opinions towards antibiotic use and resistance in the southeastern region of Hungary]. Orv Hetil. 2020; 161(9): 330-339.

(Beérkezett: 2019. július 26.; elfogadva: 2019. szeptember 20.) 


\section{Rövidítések}

$\mathrm{AAD}=($ antibiotic-associated diarrhea, dysbiosis $)$ antibiotikumokkal összefüggő hasmenés, dysbiosis; CPD $=$ (continuous professional development) folyamatos szakmai továbbképzés; NEAK = Nemzeti Egészségbiztosítási Alapkezelő; POCT = 'point-of-care' tesztek; WEF $=$ (World Economic Forum) Világgazdasági Fórum; WHO = (World Health Organization $)$ Egészségügyi Világszervezet

Az antibiotikumok a modern orvoslás nélkülözhetetlen elemei; felfedezésük óta sok millió ember életét mentették meg, akiknek előtte - az ún. preantibiotikus érában nem lett volna esélyük a túlélésre. Sem az akut fertőzések kezelése, sem pedig a különböző orvosi beavatkozások (sebészeti ellátás, szervtranszplantációk, koraszülött-ellátás, daganatos betegek kemoterápiája stb.) nem képzelhetók el ma már nélkülük [1]. Ugyanakkor a modern egészségügyi infrastruktúrával és rendszerrel rendelkező országok orvosai egyre többször kerülnek nehéz helyzetbe, amikor olyan kórokozókkal találkoznak, amelyekkel szemben nagyon kevés terápiás megoldás maradt [2-9]. Napjainkban az antibiotikumok felhasználása sokszor nem a szakmai irányelvekben/ajánlásokban foglaltak szerint történik, nem ritka, hogy nem megfelelő indikációban, gyakran klinikai mikrobiológiai vizsgálatok nélkül széles spektrumú szerek kerülnek alkalmazásra. Magyarország ebben különösen érintett, hisz míg az egy före jutó abszolút antibiotikumfogyasztás tekintetében a középmezőnyben, a szúk és széles spektrumú szerek felhasználásának arányait tekintve az egyik legrosszabb helyen vagyunk Európában [10]. Az utóbbiért leginkább a fluorokinolonok túlzott mennyiségű használata felelős: ez az antibiotikumcsoport napjainkban többnyire másodvonalbeli szerepet tölt be a terápiában, amely ellen könnyen és gyorsan alakul ki rezisztencia [11, 12]. Bár a bakteriális rezisztencia kialakulása és a rezisztens klónok szelekciója természetes törzsfejlődési folyamat, a hosszú távú, szubterápiás (azaz szubletális) dózisú antibiotikumexpozíció nagy mértékben hozzájárul a folyamat felgyorsulásához. $\mathrm{Az}$ antibiotikumrezisztencia problémája interdiszciplináris jellegú, ami a pácienseket, a felíró orvosokat, az expediáló gyógyszerészeket és a törvényhozókat egyformán érinti; megoldása közös és következetes fellépést igényel minden érintett részéről [13]. A lakossági „elvárások” és a nem megfelelő tájékozottság is felelőssé tehető a rezisztencia terjedéséért. Az átlagember a tünetei alapján nem tudja megítélni, hogy például egy felső légúti fertôzés esetén milyen gyógyszerre van szüksége, és gyakran azzal a várakozással fordul orvoshoz, hogy antibiotikumot fog kapni [14]. Az esetek többségében azonban a virális etiológia miatt nem indokolt az antibiotikum felírása, de ezzel a betegek többsége nincs tisztában; a Dél-Alföld régióban végzett lakossági felmérés szerint ugyanis a megkérdezettek 51,4\%-a úgy véli, hogy az antibiotikumok hatásosak a vírusok ellen [15]. A bakteriális multidrog-rezisztencia és a hatékony antibiotikumok hiánya súlyos népegészségügyi kockázatot jelent, olyannyira, hogy a Világgazdasági Fórum (World Economic Forum; WEF) mint a világot kiemelten fenyegető problémát jegyezte [16], és az Egészségügyi Világszervezet (World Health Organization, WHO) közleményei is a minél elóbbi beavatkozásra sürgetnek $[2,17,18]$.

A háziorvosnak, mint az egészségügyi alapellátás meghatározó szereplőjének, kiváló lehetősége van a betegek adherenciájának és megfelelő gyógyszerhasználatának növelésére, illetve a megelőzéssel, tanácsadással és betegoktatással a fertőző és nem fertőző megbetegedések viszszaszorítására [19-21]. Ebből eredően a háziorvosokat nagy felelősség is terheli, hiszen a páciensek döntő többsége rajtuk keresztül jut antibiotikumokhoz; így azért, hogy a betegek csak indokolt esetben és a kórképnek megfelelő szert kapjanak megfelelő ideig és mennyiségben, az expediáló gyógyszerészen kívül végső soron neki kell kezeskednie. Következésképpen, a háziorvosok antibiotikumokkal - ezen belül az ellenük kialakuló rezisztenciával - kapcsolatos ismereteinek szintje, vélekedésük a megelőzés szerepéről és a témával kapcsolatos hozzáállásuk döntően befolyásolhatja a rezisztenciatrendek alakulását és a betegek viszonyulását mind hazánkban, mind világszerte.

Kutatásunk célja az ország Dél-Alföld régiójában (Csongrád, Bács-Kiskun és Békés megye) tevékenykedő orvosok véleményének és attitûdjének felmérése volt az antibiotikumokkal, ezen belül is a felhasználásukkal, jelentőségükkel és az ellenük kialakuló rezisztenciával kapcsolatban, valamint az orvosok személyes felelősségérzete a helytelen antibiotikumfelhasználás elméleti és gyakorlati vonatkozásában.

\section{Módszer}

Kvantitatív vizsgálatunkat 2016 januárjában kezdtük, a lekérdezés önkitöltős, 27 pontból álló, papíralapú kérdőív segítségével történt. Az adatgyújtés a Szegedi Tudományegyetem keretein belül jellemzően háziorvosok részére szervezett három kötelező, szinten tartó továbbképzés során zajlott.

A szakirodalomra alapozott [22-24], saját fejlesztésú kérdőív fơ témakörei a következők voltak:

1. Demográfiai jellemzők (nem, életkor).

2. Munkahelyre és szakképzettségre vonatkozó adatok (a praxis helyének településtípusa, a szakvizsga típusa).

3. Az antibiotikumokkal és a rezisztenciával kapcsolatos ismeretek szubjektív megítélése.

4. Az antibiotikumok és a rezisztencia jelentőségével kapcsolatos elméleti attitúd.

5. Az antibiotikumterápia gyakorlati vonatkozásaival kapcsolatos attitűd.

6. A gyógyszerészek terápiaindikálásra vonatkozó szerepkörének kiterjesztésével kapcsolatos vélemények.

7. A prevenció fontosságának megítélése. 
A tudásra és az attitűdre vonatkozó kérdések kétféle formában kerültek megfogalmazásra: 1) egy állításról kellett eldönteni, hogy igaz/hamis; 2) vagy ötfokú skálán kellett megjelölnie a válaszadónak, hogy mennyire ért egyet egy állítással, vagy mennyire tart fontosnak egy attitűdöt; a skálán az egyik potenciális válaszlehetőség a nem tudja/bizonytalan volt.

Az elemzés során az ötfokú skálát háromfokúvá alakítottuk a következő válaszok összevonásával: 'egyáltalán nem ért egyet' és 'nem ért egyet'; 'egyetért' és 'teljesen egyetért'; 'mindig fontosnak tartom' és 'általában fontosnak tartom'; 'általában nem tartom fontosnak' és 'soha nem tartom fontosnak', valamint a nem tudja/bizonytalan kategóriát alkalmaztuk.

\section{Statisztikai elemzések}

A leíró elemzés után először a demográfiai és munkahelyi változók függvényében elemeztük a többi paramétert; majd az egyes témakörök közötti összefüggéseket vizsgáltuk.

A minta deskriptív analízise során a folytonos változók esetében átlagokat, míg a kategorikus változóknál gyakoriságokat vizsgáltunk. Elemzésünkben minden esetben az érvényes válaszok számát vizsgáltuk. Kereszttábla-elemzéseknél az összefüggések megállapítására $\chi^{2}$-próbát alkalmaztunk. Az elméleti, gyakorlati és prevenciós attitűd, valamint a szubjektív ismeretszint közötti kapcsolatot a Spearman-féle korrelációs együttható alapján analizáltuk. Eredményeinket $\mathrm{p}<0,05$ alatt tekintettük szignifikánsnak. Az adatok statisztikai elemzése SPSS 24.0 (IBM Corporation, Armonk, NY, Amerikai Egyesült Államok [USA]) programmal történt.

\section{Kutatásetika}

A kutatást a Szegedi Tudományegyetem Szent-Györgyi Albert Klinikai Központjának Regionális Humán Orvosbiológiai Tudományos és Kutatásetikai Bizottsága enge-

1. táblázat $\mid$ Az orvosok vélekedése saját ismereteikre vonatkozóan

\begin{tabular}{lccc}
\hline & Igaz & $\begin{array}{l}\text { Nem tudja/ } \\
\text { bizonytalan }\end{array}$ & Hamis \\
\hline $\begin{array}{l}\text { A fertózó betegségek patomechaniz- } \\
\text { musával és prevenciójával kapcsolatos }\end{array}$ & $79,8 \%$ & $11,5 \%$ & $8,7 \%$ \\
$\begin{array}{l}\text { ismereteim megfelelőek }(\mathrm{n}=104) \\
\begin{array}{l}\text { Szakmai ismereteim az antibakteriális } \\
\text { terápiára vonatkozóan megfelelóek } \\
(\mathrm{n}=104)\end{array}\end{array}$ & $79,8 \%$ & $14,4 \%$ & $5,8 \%$ \\
$\begin{array}{l}\text { A bakteriális rezisztenciával kapcsola- } \\
\text { tos ismereteim megfelelóek (n=104) }\end{array}$ & $48,1 \%$ & $33,7 \%$ & $18,3 \%$ \\
$\begin{array}{l}\text { Az egyetemi képzés során lehetne } \\
\text { hangsúlyosabb az antibiotikumok } \\
\text { használatával kapcsolatos oktatás } \\
\text { (n=105) }\end{array}$ & $80,0 \%$ & $11,4 \%$ & $8,6 \%$ \\
\hline
\end{tabular}

délyezte (az etikai engedély azonosítója: 3688). A kérdőív kitöltése tájékozott beleegyezést követően történt, anonim módon.

\section{Eredmények}

A kérdőívet 105 orvos töltötte ki (58,3\%-uk háziorvosi szakvizsgával rendelkezett), a válaszadási arány 48,8\% volt. A kitöltők $60,2 \%$-a nő volt; átlagéletkoruk 52,5 év; 12,5\% 0-35 év közötti, 24,0\% 36-50 év közötti, 42,3\% 51-64 év közötti és 21,2\% 65-74 év (nyugdíjkorúak) közötti életkorral; 58,3\%-uk háziorvosi szakvizsgával rendelkezett, 71,6\%-ban városi elhelyezkedésű praxissal.

\section{Az antibiotikumokkal és a rezisztenciával kapcsolatos ismeretek szubjektív megitélése}

A háziorvosoknak a saját, antibiotikumokkal kapcsolatos ismereteikkel való elégedettségét illetően (1. táblázat) elmondható, hogy a megkérdezettek közel $80 \%$-a elégedettnek bizonyult a fertőző betegségek lefolyásával, illetve az antibiotikumterápiával kapcsolatos ismereteiket illetően. Ez az arány majdnem a felére $(79,8 \%$ vs. $48,1 \%)$ csökkent, amikor az antibiotikumrezisztenciával kapcsolatos ismeretekről kérdeztünk (1. táblázat). 80\% szerint további, antibiotikumokkal kapcsolatos oktatásra lenne szükség az orvosi egyetemeken - feltételezhető, hogy a szinten tartó továbbképzéseknél hasonlóan fennáll az igény ezen témák szélesebb körü feldolgozására.

\section{Az antibiotikumok és a rezisztencia jelentôségével kapcsolatos elméleti attitüd}

A válaszadók 83,8\%-a nyilatkozott úgy, hogy járványügyi kötelessége, hogy biztosítsa fertőzésben szenvedő betegének a megfelelő terápiát - jelentse ez akár a baktérium-, vírus-, gomba- vagy féregellenes szerek felírását; $5,7 \%$ bizonytalan volt a válaszában, míg 10,5\% nem értett egyet ezzel az állítással. A kérdőívet kitöltők 92,3\%-a véli úgy, hogy hatékony munkájához szükséges, hogy megismerje a gyógyszerkincsben jelenleg megtalálható antibiotikumokat, illetve a gyógyszerpiacon újonnan megjelenő termékeket.

Általánosságban elmondható, hogy a vizsgált háziorvosok döntő többsége tudatában van annak, hogy a nem megfelelő antibiotikumhasználat milyen következményekkel járhat: 92,4\% szerint az antibiotikumok kiemelt jelentőségű gyógyszercsoport, míg a megkérdezettek 93,3\%-a helytelen használatukat komoly egészségügyi problémának tekinti (a legkevésbé a 36-50 évesek szerint probléma $[\mathrm{p}=0,018])$. A nem megfelelően választott antibiotikumterápia $82,8 \%$ szerint éves szinten jelentôs többletköltséget okoz az egészségügyben.

A megkérdezettek 72,4\%-a úgy gondolja, hogy az antibiotikumok használata az állattenyésztésben (mint hozamfokozó szerek, illetve profilaktikusan, az állo- 
mányban könnyen elterjedő fertőző megbetegedések megelőzésére) legalább olyan fontos tényezője a bakteriális rezisztencia kialakulásának, mint a nem megfeleló indikációban történő felhasználásuk az egészségügyben, ám 17,1\% nem tudta eldönteni az állítás helyességét.

Vizsgáltuk azt is, hogyan vélekednek az Országos Egészségbiztosítási Pénztár (jogutódja a Nemzeti Egészségbiztosítási Alapkezelő; NEAK) antibiotikumokra vonatkozó finanszírozásáról, támogatási szintjéről - a legtöbb válaszadó $(38,5 \%)$ elégedetlen, míg $29,8 \%$ elégedett, és $31,7 \%$ bizonytalan a kérdést illetően.

\section{Az antibiotikumterápia gyakorlati vonatkozásaival kapcsolatos attituld}

A megkérdezettek önálló becslései alapján a többség $(62,9 \%)$ praxisában (1. ábra) a betegek 5-10\%-ának írnak fel antibiotikumra vonatkozó vényt a rendeléseik során, míg a válaszadók egyötöde $(21,7 \%)$ szerint ez az érték akár több mint $20 \%$ is lehet. Csak a válaszadók 71,4\%-a szerint jelent problémát a széles spektrumú antibiotikumok túlzott használata; $21,0 \%$ szerint - mivel ezek a szerek a baktériumok nagyobb számára hatnak egy idôben - megnövelik a terápiás siker arányát, illetve lerövidítik a kezelés idejét.

Rendeléseik során a válaszadók 43,3\%-a mindig fontosnak tartja, közel fele $(49,0 \%)$ pedig általában figyel arra, hogy kitérjen az antibiotikumok helyes alkalmazásának részleteire, csökkentve ezzel a gyógyszerelési hibák előfordulását. Az antibiotikumterápia által következetesen okozott mellékhatások (AAD: antibiotic-associated

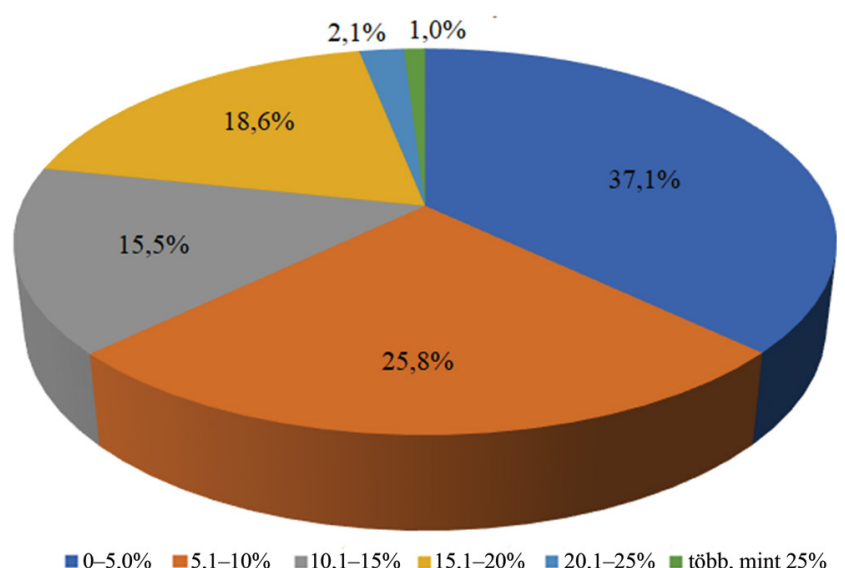

1. ábra

A megkérdezettek önálló becslései arra vonatkozóan, hogy az általuk kezelt páciensek hány százaléka távozik antibiotikumra vonatkozó vénnyel

diarrhea, dysbiosis) kiküszöbölése érdekében $82,7 \%$ fontosnak tartja a probiotikumok ajánlását.

A megkérdezettek csupán 69,2\%-a tartja döntő fontosságúnak a fertőzést okozó kórokozók klinikai mikrobiológiai identifikálását, vagy 'point-of-care' tesztek (POCT) alkalmazását a mindennapi gyakorlatban, a megfelelő diagnózis és terápia kiválasztásának érdekében.

A megkérdezett háziorvosok negyede $(25,0 \%)$ elismerte, hogy a betegek temperamentuma alapvetően befolyásolja a gyógyszerfelírási szokásait rendelése során; $71,2 \%$ nem értett egyet ezzel az állítással, míg 3,8\% bizonytalan volt a válaszban (2. táblázat).

2. táblázat |Az orvosok vélekedése a saját szerepkörükrool és a külső tényezốk szerepérôl

\begin{tabular}{|c|c|c|c|c|c|}
\hline & \multicolumn{2}{|c|}{ Egyetért } & \multirow{2}{*}{$\begin{array}{l}\text { Nem tudja/ } \\
\text { bizonytalan }\end{array}$} & \multicolumn{2}{|c|}{ Nem ért egyet } \\
\hline & $\begin{array}{l}\text { Teljesen } \\
\text { egyetért }\end{array}$ & Egyetért & & Nem ért egyet & $\begin{array}{l}\text { Egyáltalán nem } \\
\text { ért egyet }\end{array}$ \\
\hline $\begin{array}{l}\text { A betegek temperamentuma alapvetően befolyásolja } \\
\text { gyógyszerfelírási szokásaimat }(\mathrm{n}=105)\end{array}$ & $6,7 \%$ & $18,3 \%$ & $3,8 \%$ & $50,0 \%$ & $21,2 \%$ \\
\hline Összesitve: & \multicolumn{2}{|c|}{$25,0 \%$} & $3,8 \%$ & \multicolumn{2}{|c|}{$71,2 \%$} \\
\hline $\begin{array}{l}\text { A megfelelö betegoktatás hatékonyan csökkentené a fertőző } \\
\text { betegségek előfordulását }(\mathrm{n}=105)\end{array}$ & $39,0 \%$ & $42,9 \%$ & $7,6 \%$ & $10,5 \%$ & $3,8 \%$ \\
\hline Összesitve: & \multicolumn{2}{|c|}{$81,9 \%$} & $7,6 \%$ & \multicolumn{2}{|c|}{$14,3 \%$} \\
\hline $\begin{array}{l}\text { A média elég energiát fordít a fertőző betegségekkel } \\
\text { kapcsolatos ismeretterjesztésre }(\mathrm{n}=105)\end{array}$ & $1,0 \%$ & $16,2 \%$ & $3,8 \%$ & $53,3 \%$ & $25,7 \%$ \\
\hline Összesitve: & \multicolumn{2}{|c|}{$17,2 \%$} & $3,8 \%$ & \multicolumn{2}{|c|}{$79,0 \%$} \\
\hline $\begin{array}{l}\text { Rendelésem során nemcsak az akutan fennálló fertózéssel } \\
\text { kapcsolatban kell terápiás döntést hoznom, hanem életmódi } \\
\text { tanácsokkal is el kell látnom a beteget }(\mathrm{n}=105)\end{array}$ & $47,1 \%$ & $46,2 \%$ & $2,9 \%$ & $2,9 \%$ & $1,0 \%$ \\
\hline Összesitve: & \multicolumn{2}{|c|}{$93,3 \%$} & $2,9 \%$ & \multicolumn{2}{|c|}{$3,9 \%$} \\
\hline $\begin{array}{l}\text { A beteg tájékoztatása során fontosnak tartom, hogy kitérjek } \\
\text { az antibiotikumok helyes használatának minden részletére } \\
(\mathrm{n}=105)\end{array}$ & $43,3 \%$ & $49,0 \%$ & $1,0 \%$ & $6,7 \%$ & $0 \%$ \\
\hline Összesitve: & \multicolumn{2}{|c|}{$92,3 \%$} & $1,0 \%$ & \multicolumn{2}{|c|}{$6,7 \%$} \\
\hline $\begin{array}{l}\text { Fontosnak tartom a probiotikumokat a terápiás mellékhatások } \\
\text { csökkentése érdekében }(\mathrm{n}=105)\end{array}$ & $42,3 \%$ & $40,4 \%$ & $1,0 \%$ & $15,4 \%$ & $1,0 \%$ \\
\hline Összesitve: & \multicolumn{2}{|c|}{$82,7 \%$} & $1,0 \%$ & \multicolumn{2}{|c|}{$16,4 \%$} \\
\hline
\end{tabular}


3. táblázat |Az orvosok vélekedése a gyógyszerészi szerepkörről antibiotikumterápia esetén

\begin{tabular}{|c|c|c|c|c|c|}
\hline & \multicolumn{2}{|c|}{ Egyetért } & \multirow{2}{*}{$\begin{array}{l}\text { Nem tudja/ } \\
\text { bizonytalan }\end{array}$} & \multicolumn{2}{|c|}{ Nem ért egyet } \\
\hline & $\begin{array}{l}\text { Teljesen } \\
\text { egyetért }\end{array}$ & Egyetért & & Nem ért egyet & $\begin{array}{l}\text { Egyáltalán nem } \\
\text { ért egyet }\end{array}$ \\
\hline $\begin{array}{l}\text { A gyógyszerészek tanácsai a gyógyszerkiadás során legalább } \\
\text { olyan fontosak, mint az orvos utasításai }(\mathrm{n}=105)\end{array}$ & $17,1 \%$ & $55,2 \%$ & $6,8 \%$ & $19,0 \%$ & $1,9 \%$ \\
\hline Összesitve: & \multicolumn{2}{|c|}{$72,3 \%$} & $6,8 \%$ & \multicolumn{2}{|c|}{$20,9 \%$} \\
\hline $\begin{array}{l}\text { Az antibiotikumterápiával kapcsolatos gondozási feladatokat } \\
\text { bizalommal adnám át a gyógyszerésznek }(\mathrm{n}=105)\end{array}$ & $3,8 \%$ & $14,3 \%$ & $4,8 \%$ & $44,8 \%$ & $32,4 \%$ \\
\hline Összesitve: & \multicolumn{2}{|c|}{$18,1 \%$} & $4,8 \%$ & \multicolumn{2}{|c|}{$77,2 \%$} \\
\hline $\begin{array}{l}\text { Bizonyítottan szövődménymentes fertőzések esetén a } \\
\text { gyógyszerészek is elláthatnák a terápia feladatát }(\mathrm{n}=105)\end{array}$ & $1,9 \%$ & $17,1 \%$ & $3,8 \%$ & $46,7 \%$ & $30,5 \%$ \\
\hline Összesitve: & \multicolumn{2}{|c|}{$19,0 \%$} & $3,8 \%$ & \multicolumn{2}{|c|}{$77,2 \%$} \\
\hline
\end{tabular}

\section{A gyógyszerészi szerepkör kiterjesztésével kapcsolatos vélekedés}

Kutatásunk során felmértük, hogyan vélekednek a hazánkban dolgozó orvosok a közforgalmú gyógyszerészek fertőző betegségekre vonatkozó funkcióinak kiszélesítésérôl (3. táblázat). Eredményeink tükrében elmondható, hogy míg a megkérdezett háziorvosok többsége egyetért azzal, hogy a gyógyszerészek által az expediálás során közölt információk fontos tényezői a megfelelő gyógyszeres terápiának (72,3\%), az antibiotikumterápia kiválasztását és az azzal járó gondozási feladatokat a megkérdezettek több mint háromnegyede $(77,2 \%)$ már nem bízná a patikákban dolgozó gyógyszerész kollégákra (3. táblázat). Ezen gyógyszerészi szerepkörök kiterjesztését leginkább az 51 éven felüli orvosok utasítják el. A városi elhelyezkedésű praxissal rendelkező orvosok közül többen ellenzik a gondozási feladatok átadását a gyógyszerészeknek, mint a kisebb településen praktizáló orvosok $(\mathrm{p}=0,028)$. Azon válaszadók, akik szívesen átadnák a terápia kiválasztásának feladatát a gyógyszerészeknek, kevésbé részletezik az antibiotikumhasználatot a betegek tájékoztatása során $(\mathrm{p}=0,001)$, valamint kevésbé akarják megismerni a gyógyszerkincsben található antibiotikumokat $(\mathrm{p}<0,001)$. Azokat az orvosokat jobban befolyásolja a betegek temperamentuma a gyógyszerfelírás során, akik nem tartják fontosnak a gyógyszerészek tanácsait gyógyszerkiadáskor $(\mathrm{p}=$ 0,042 ).

\section{A prevenció fontosságának megitélése}

A megkérdezett háziorvosok 81,9\%-a egyetért azzal, hogy a megfelelő betegoktatás szignifikánsan csökkentené a fertőző betegségek előfordulását (2. táblázat). Ennek fényében nem meglepő, hogy a kutatásban részt vevők saját bevallásuk szerint 30,5\%-ban mindig, $58,1 \%$-ban pedig általában adnak tanácsot a hozzájuk forduló pácienseknek a fertôző betegségek prevenciójával kapcsolatban. A prevenciós tanácsadásra nagyobb hangsúlyt fektető orvosok többsége háziorvos $(\mathrm{p}=0,033)$. A válaszadók 93,3\%-a értett egyet azzal az állásponttal, miszerint háziorvosi praxisuk során nemcsak az akutan fennálló fertőzéssel kapcsolatban kell terápiás döntést hozniuk, hanem életmódi tanácsokkal is fontos ellátniuk betegeiket (2. táblázat). A külső tényezők szerepérôl $79,0 \%$ gondolja úgy, hogy a média a fertőző betegségekkel kapcsolatos ismeretterjesztés fontos eszköze lehetne, erre azonban nem fordítanak megfelelő energiát (2. táblázat).

\section{Az ismeretszint és az egyes attitüdök összefüggései}

A szubjektíven megítélt ismeretszint nem feltétlenül jó indikátora a helyes attitúdnek. Általában a szubjektíven megítélt megfelelő ismeretszint gyenge erôsségú, de pozitív és szignifikáns korrelációt mutatott számos elméleti és prevenciós attitúddel. Azok az orvosok viszont, akik akár az antibiotikumterápiával, akár a fertőző betegségek patomechanizmusával és prevenciójával vagy a bakteriális rezisztenciával kapcsolatban szubjektíven magasabb tudással rendelkeztek, inkább adtak tanácsot a fertőző betegségek megelőzési lehetőségeivel kapcsolatosan, mint az alacsonyabb ismerettel rendelkező kollégák. Ám a helyes attitűd sokszor az őszintén bevallott ismerethiánnyal mutatott összefüggést, vagy a helyes attitüd nem mutatott korrelációt a magasabb tudással. A bakteriális rezisztenciával tisztában lévő orvosok inkább érzékelték, hogy a helytelen antibiotikumhasználat többletköltséget ró az egészségügyre, valamint ôk fontosnak tartották az új antibiotikumok megismerését (4. táblázat).

Az általunk vizsgált elméleti attitúdre vonatkozó állítások helyes felismerése szignifikáns, pozitív korrelációt mutatott szinte az összes megfelelő gyakorlati és prevenciós eljárással. A leginkább az újonnan piacra kerülő antibiotikumok megismerésének igénye járt együtt a helyes gyakorlati és prevenciós tevékenységekkel; a legerősebb pozitív korrelációt a megfelelő antibiotikumhasználat beteg felé történő részletezésével kapcsolatban találtuk. Annak megértése, hogy a gyógyszert felíró orvosnak járványügyi kötelessége biztosítani a legmegfelelőbb terápi- 
4. táblázat |A szubjektíven megítélt ismeretszint korrelációja az elméleti, gyakorlati és prevenciós attitúddel a Spearman-féle korrelációs együttható alapján

\begin{tabular}{|c|c|c|c|c|}
\hline & & \multicolumn{3}{|c|}{ Megfelelő ismeretszint } \\
\hline & & Antibiotikumterápia & $\begin{array}{c}\text { A fertőző } \\
\text { betegségek } \\
\text { patomechanizmusa } \\
\text { és prevenciója }\end{array}$ & $\begin{array}{l}\text { Bakteriális } \\
\text { rezisztencia }\end{array}$ \\
\hline \multirow{7}{*}{$\begin{array}{l}\text { Elméleti } \\
\text { attitüd }\end{array}$} & $\mathrm{Az} \mathrm{AB}-\mathrm{ok}$ helytelen használata probléma & $-0,134$ & $-0,134$ & $-0,010$ \\
\hline & A helytelen használat többletköltséget okoz & 0,164 & 0,153 & $0,205^{*}$ \\
\hline & Az állattenyésztésnek szerepe van az AB-rezisztenciában & $-0,042$ & 0,015 & 0,093 \\
\hline & $A z$ új $A B$-ok megismerése fontos & $-0,146$ & $-0,046$ & $0,227^{*}$ \\
\hline & $\mathrm{Az} \mathrm{AB}$-ok kiemelt jelentőségú szerek & $-0,144$ & $-0,051$ & 0,134 \\
\hline & Nem ért egyet a NEAK (OEP) AB-finanszírozási szabályával & $-0,032$ & 0,026 & $-0,166$ \\
\hline & Járványügyi kötelesség biztosítani a legmegfelelőbb terápiát & $-0,034$ & 0,100 & $-0,036$ \\
\hline \multirow{6}{*}{$\begin{array}{l}\text { Gyakorlati } \\
\text { attitűd }\end{array}$} & Ritkább AB-felírási szokás & 0,057 & 0,044 & 0,035 \\
\hline & A széles spektrumú AB-ok túlzott használata probléma & 0,049 & 0,050 & $-0,138$ \\
\hline & A helyes AB-használatot részletezi a páciensnek & $-0,061$ & $-0,045$ & 0,188 \\
\hline & A betegek temperamentuma nem befolyásolja a gyógyszerfelírást & 0,160 & 0,168 & 0,188 \\
\hline & Probiotikumot ajánl az AB mellé & 0,021 & 0,085 & 0,137 \\
\hline & A kórokozók kitenyésztése fontos & 0,062 & $-0,103$ & $-0,080$ \\
\hline \multirow{4}{*}{$\begin{array}{l}\text { Prevenciós } \\
\text { attitűd }\end{array}$} & A megfelelő betegoktatás csökkentené a fertőző betegségeket & 0,120 & 0,087 & 0,057 \\
\hline & Tanácsadás a fertőző betegségek prevenciójáról & $0,200 *$ & $0,321 * *$ & 0,295 ** \\
\hline & Életmódi tanácsokkal kell ellátni a beteget & 0,036 & $0,259 * *$ & 0,148 \\
\hline & $\begin{array}{l}\text { A média nem fordít elég energiát a fertőző betegségekkel } \\
\text { kapcsolatos ismeretterjesztésre }\end{array}$ & $-0,030$ & 0,042 & 0,110 \\
\hline
\end{tabular}

*a korreláció szignifikáns $\mathrm{p}<0,05$ szinten; **a korreláció szignifikáns $\mathrm{p}<0,01$ szinten

$\mathrm{AB}=$ antibiotikum; NEAK = Nemzeti Egészségbiztosítási Alapkezelő

át, együtt járt a ritkább antibiotikumfelírási szokással. Annak felismerése, hogy a humángyógyászaton kívül az állatgyógyászat is felelős a globális antibiotikumrezisztencia-viszonyok kialakulásáért, szintén arra késztette az orvosokat, hogy kevesebb antibiotikumot írjanak fel praxisukban; a széles spektrumú antibiotikumok túlzott használatát nagyobb problémának vélték; valamint ók érzékelték, hogy a média nem fordít elég időt a fertôzô betegségekkel kapcsolatos ismeretterjesztésre. Azon elméleti attitúd formálásával, hogy a helytelen használat többletköltséget okoz, együtt járt az a helyes gyakorlat, hogy a betegek temperamentuma nem befolyásolja a gyógyszerfelírást; valamint az a helyes prevenciós attitűd, hogy a megfelelő betegoktatás képes csökkenteni a fertőzó betegségek előfordulását. Annak megértése, hogy az antibiotikumok helytelen használata problémát jelent, szoros korrelációban állt azzal a pozitív attitúddel, hogy az orvos a helyes antibiotikumhasználatot részletezi a páciensnek; valamint szintén azzal a kedvező vélekedéssel, hogy a betegoktatás csökkentheti a fertőző betegségek morbiditáát. Az elméleti attitűd formálásával együtt jár a probiotikumok gyakoribb ajánlása antibiotikumkúra esetén. A kórokozók kitenyésztésének fontosságát nem sikerül növelni az elméleti tudás emelésével, ami arra enged következtetni, hogy a mikrobiológiai meghatározás elrendelésének más gátjai lehetnek (például financiális). A széles spektrumú antibiotikumok túlzott használata, valamint az antibiotikumfelírási gyakoriság szintén nem mutatott semmilyen korrelációt az elméleti attitűddel. Kiemelendő, hogy az elméleti vonatkozások magas szintú ismerete azt is jelenti, hogy az orvosok nemcsak a fertőző betegségekkel kapcsolatban adnak tanácsot a betegeknek, hanem a nem fertőző betegségek tekintetében életmódi tanácsokkal is jobban ellátják a pácienseket (5. táblázat).

A pozitív prevenciós attitűd szintén számos szignifikáns korrelációt mutatott a gyakorlati tevékenységek helyes kivitelezésével; a leginkább a megfelelő antibiotikumhasználat részletezése vált gyakoribbá a megfelelő prevenciós attitűddel rendelkező orvosok körében (6. táblázat).

\section{Megbeszélés}

Vizsgálatunk középpontjában a Dél-Alföld régióban dolgozó háziorvosok antibiotikumfelhasználással és -rezisztenciával, illetve a fertőző betegségek prevenciójával kapcsolatos ismeretei és attitűdjei álltak. Eredményeink alapján elmondható, hogy a válaszadó egészségügyi szakemberek többsége biztos a tudásában, és a tőle el- 
5. táblázat |Az elméleti attitűd korrelációja a gyakorlati és prevenciós attitűddel a Spearman-féle korrelációs együttható alapján

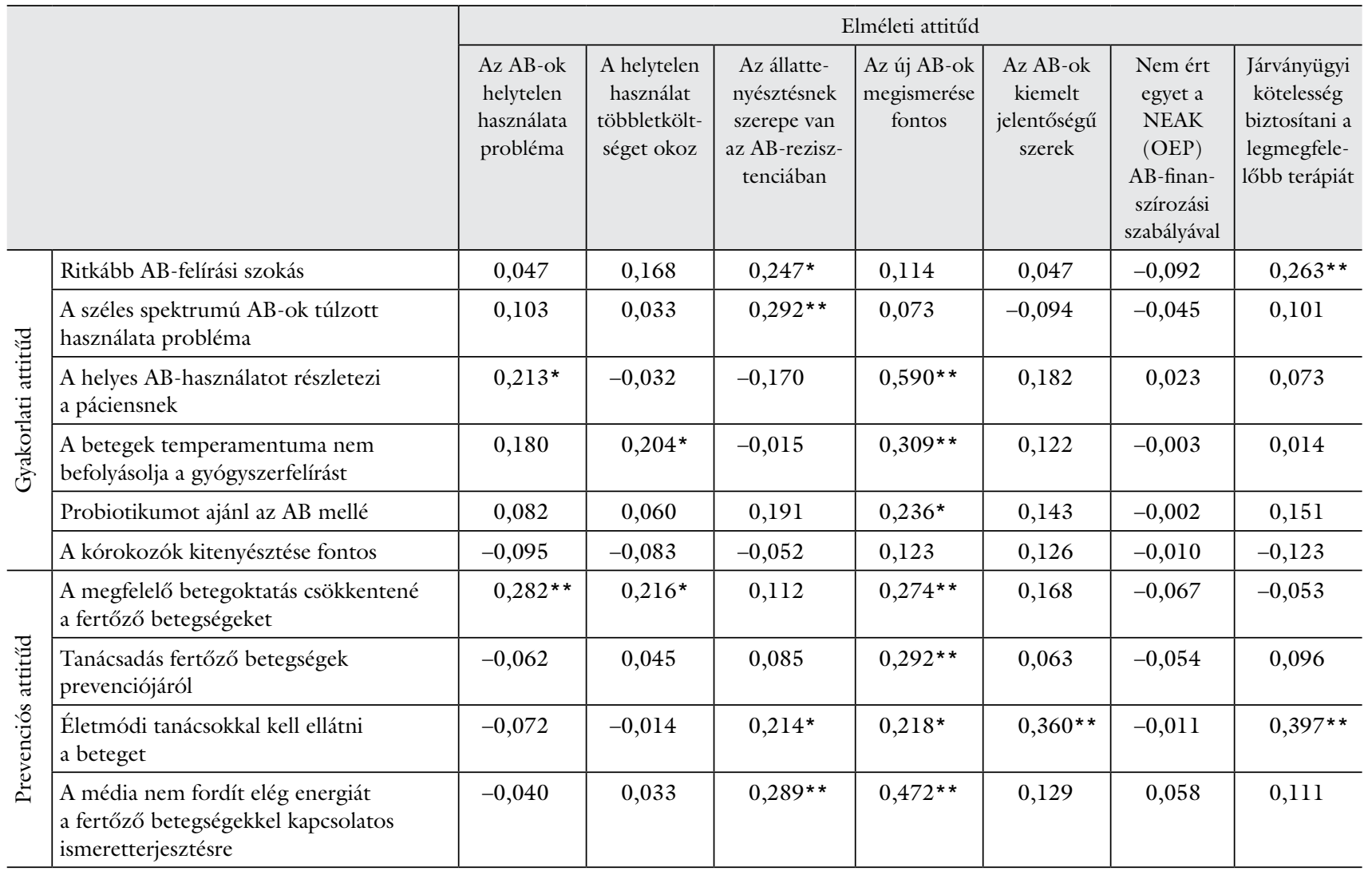

*a korreláció szignifikáns p $<0,05$ szinten; **a korreláció szignifikáns $\mathrm{p}<0,01$ szinten

$\mathrm{AB}=$ antibiotikum

6. táblázat |A prevenciós attitűd korrelációja a gyakorlati attitűddel a Spearman-féle korrelációs együttható alapján

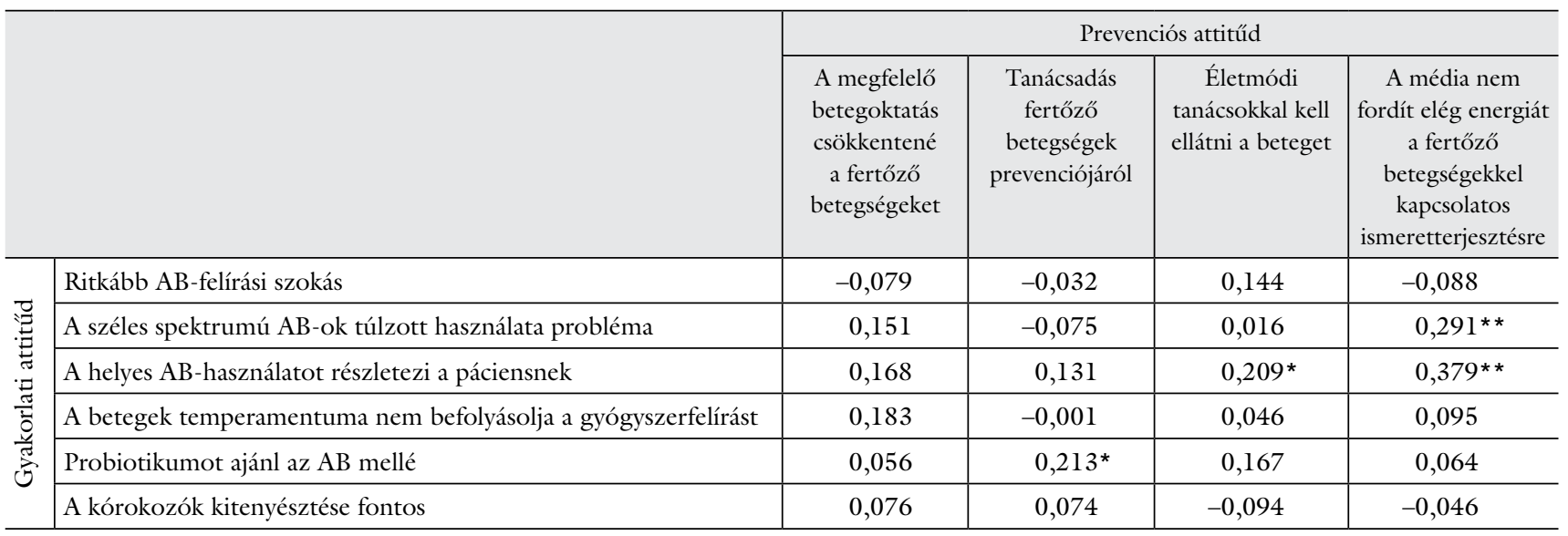

*a korreláció szignifikáns $\mathrm{p}<0,05$ szinten; * *a korreláció szignifikáns $\mathrm{p}<0,01$ szinten

$\mathrm{AB}=$ antibiotikum

várt tudásszinttel rendelkezik, tehát kisebbségben vannak azok, akik még nem ismerték fel azt a veszélyt, amelyet az antibiotikumrezisztencia jelent az egészségügy, illetve a társadalom egésze számára, vagy még nem biztosak abban, hogy mint háziorvosnak, mi a szerepük a rezisztenciakrízis elkerülésében. Ez utóbbi határvonal felismerése központi jelentőségú, hisz napjaink egyik legnagyobb problémáját pont az jelenti, hogy olyan, vírusok által okozott kórképekben is felírásra kerülnek antibiotikumok, amikor ez szakmai szempontból (kivéve 
profilaktikusan) nem lenne indokolt (becslések szerint a felső légúti fertőzések, akut tonsillitis, sinusitis, akut otitis media, bronchitis 70-80\%-a virális eredetü) [25]. Különösen fontos ez, hisz a megkérdezett orvosok saját bevallása szerint azon páciensek száma, akik a rendelésükről antibiotikumra vonatkozó vénnyel távoznak, akár a $20 \%$-ot is kiteheti. Ez feltehetően azzal magyarázható, hogy míg az antibiotikumok farmakológiájával, illetve a különböző fertőző kórképekkel és kezelésükkel a (leendő és) praktizáló orvosok egyetemi tanulmányaik során többször találkoznak, a különböző rezisztenciamechanizmusokkal már sokkal kevésbé és felületesebben foglalkozik a curriculum [26, 27]. A legtöbb háziorvos egyetértett abban, hogy a megelőzés vitathatatlan fontosságú a fertőző betegségek incidenciájának csökkentése szempontjából, és - saját bevallásuk szerint - tevékenyen és aktívan részt vesznek a betegek ismereteinek gyarapításában. Míg hazánkban a gyógyszerészek szerepköre az antibiotikumterápiára vonatkozóan kimerül a gyógyszerek expediálásában, az interakció keresésében és a terápiás tanácsadásban (a gyógyszerészi gondozás keretein belül), egyes országokban (USA, Kanada, Egyesült Királyság, Új-Zéland), ahol az egészségügyi rendszer a hazánkétól eltérő felépítésű, a közforgalomban dolgozó gyógyszerészek a terápia kiválasztásának és menedzsmentjének fontos résztvevői [28-31]. A megkérdezett háziorvosok elismerték a gyógyszerészek szerepét a megfelelő gyógyszeres terápiában, azonban terápiás döntést és ún. felírási jogkört (ún. prescribing pharmacists) már nem bíznának a gyógyszerész kollégákra.

Kutatásunk eredményeinek értékelése során kevés szignifikáns összefüggést találtunk a válaszok és az életkor, a válaszadó neme, a szakvizsga megléte, illetve a praxis helye között. Ez arra enged következtetni, hogy a vizsgált témákra vonatkozó ismeretek és a nézetek nem mutatnak differenciált eloszlást a megkérdezett háziorvosok körében, nem köthetők igazán egyik vizsgált tényezőhöz sem. A különböző kötelező, szinten tartó továbbképzések, tréningek és előadások kiemelt jelentôségüek lehetnek a háziorvosok ismereteinek kiegészítésében és bővítésében s hozzáállásuk fejlesztésében, hogy tevékeny szereplői legyenek azon az egészségügyben dolgozóknak, akik tesznek az antibiotikumrezisztencia csökkentése érdekében [32].

Habár a vizsgált minta elemszáma kicsi volt, a hibás elméleti vélekedés és a helytelen gyakorlati attitüd számos háttértényezőjét azonosítottuk. Az ismeretek hiánya mind az elméleti, mind a gyakorlati attitűdre negatív hatással lehet. A hibás elméleti vélekedések nemcsak hibás gyakorlati megnyilvánuláshoz vezethetnek, de a helytelen prevenciós attitüdhöz is hozzájárulnak; ezért az elméleti tudás fejlesztése mind a graduális, mind a posztgraduális képzésben alapvető fontosságú. A graduális orvosképzés során mind az elméleti (például orvosi mikrobiológia), mind a klinikai tárgyak (például belgyógyászat-infektológia) oktatása során, illetve a záróvizsgakövetelmények meghatározásakor nagyobb hangsúlyt szükséges fordítani a megfelelő antibiotikumutilizáció és az antibiotikumrezisztencia tárgykörére, hogy a pályakezdő orvosok már megfelelő szemlélettel kezeljék betegeiket. Hasonlóan fontos szereppel bírnak a továbbképző, szinten tartó tanfolyamok is, amelyeken lehetőség nyílik az antibiotikumrezisztencia-probléma súlyosságának hangsúlyozására és a szemléletváltoztatásra a tapasztalt orvoskollégák körében.

A jelen kutatás hiányosságaként felróható, hogy Magyarország egy meghatározott földrajzi régiójára korlátozódott (Dél-Alföld régió), egy relatíve kis elemszámú mintán. Ahhoz, hogy általános következtetéseket tudjunk levonni a hazai orvosok vélekedéséről, a kutatást kívánatos lenne kiegészíteni az ország egyéb területein tevékenykedő szakemberek bevonásával. Érdekes jövőbeli kutatási irányvonal lehet a fekvőbeteg-szakellátásban vagy a specializált egészségügyi centrumokban dolgozó szakemberek vélekedésének vizsgálata.

Az antibiotikumrezisztenciával kapcsolatos attitüd fejlesztésének további pozitív hozadéka lehet, hogy nemcsak a fertőző betegségek iránt érzékenyíti az orvosokat, hanem az életmóddal összefüggő nem fertőző betegségek irányában is. Az orvosoknak alapvető feladatuk az egészségfejlesztés, és a pozitív egészségmagatartás kialakítása mindenféle populációban kiemelt fontosságú [33, 34].

A válaszadók között kisebb arányban vannak azok, akik még nem ismerik fel az antibiotikumrezisztencia veszélyeit és saját szerepüket a megfelelő gyógyszerfelhasználás elősegítésében, ami a rezisztenciaproblémával kapcsolatos felhalmozott tudományos evidencia tükrében nem fogadható el - minden praktizáló orvosnak tisztában kell lennie felelősségével és a prevenciós lehetőségekkel. A praktizáló orvosoknak a védőoltások ajánlásával kapcsolatos felelősségi köréhez hasonlóan a jelen egészségügyi szakembereknek a betegek kezelése során biztosítaniuk kell, hogy az antibiotikumok csak adekvát indikációban kerüljenek alkalmazásra (támaszkodva a graduálisan, illetve posztgraduálisan megszerzett ismereteikre) [35]. Az egészségügyi dolgozók helyes attitúdjének és minimálisan elvárt ismeretszintjének kialakításához az antimikrobiális 'stewardship' részeként nagy segítséget ad a WHO által 2018-ban kidolgozott kompetencia-keretrendszer [36], amelyet mind a graduális, mind a posztgraduális képzésben Magyarországon is hasznosítani lehetne. Ez a rendszer az orvosokra vonatkozó kompetenciák közt mindazon elméleti és gyakorlati elemeket hangsúlyozza, amelyek a jelen kutatásban is a kérdőív kérdései között szerepeltek.

Anyagi támogatás: A közlemény létrejöttét az NTPNFTÖ-18-C-0225 „Nemzet Fiatal Tehetségeiért Ösztöndíj” támogatta.

Szerzői munkamegosztás: G. M.: A vizsgálat tervezése, lefolytatása, az adatok kiértékelése, a kézirat megszöve- 
gezése. Sz. A.: A vizsgálat tervezése, az adatok kiértékelése, a kézirat megszövegezése, kritikus átolvasása. A közlemény végleges változatát mindkét szerző elolvasta és jóváhagyta.

Érdekeltségek: A szerzőknek nincsenek érdekeltségeik.

\section{Köszönetnyilvánítás}

A szerzők köszönetüket fejezik ki a kérdőívet kitöltő háziorvosoknak és a kitöltést koordináló kollégáknak, akik közremúködésükkel lehetôvé tették a kutatás lefolytatását.

\section{Irodalom}

[1] Szúcs O, Kristóf K, Darvas K, et al. Changes in the incidence of multiresistant pathogens and its consequences in intensive care unit. [Multirezisztens kórokozók gyakoriságának változása és ennek vonatkozásai az intenzív osztályon.] Orv Hetil. 2011; 152: 1486-1491. [Hungarian]

[2] European Centre for Disease Prevention and Control. Last-line antibiotics are failing: options to address this urgent threat to patients and healthcare systems. ECDC, Stockholm, 2016. Available from: https://www.ecdc.europa.eu/en/publicationsdata/last-line-antibiotics-are-failing-options-address-urgentthreat-patients-and [accessed: July 15, 2019].

[3] World Health Organization. Antimicrobial resistance: global report on surveillance. WHO, Geneva, 2014; pp. 1-256. Available from: http://apps.who.int/iris/bitstream/10665/112642/1/ 9789241564748_eng.pdf [accessed: July 15, 2019].

[4] Gajdács M. The continuing threat of methicillin-resistant Staphylococcus aureus. Antibiotics (Basel) 2019; 8: E52.

[5] European Centre for Disease Prevention and Control. Surveillance of antimicrobial consumption in Europe 2012. ECDC, Stockholm, 2014. Available from: https://www.ecdc.europa. $\mathrm{eu} / \mathrm{en} /$ publications-data/surveillance-antimicrobial-consumption-europe-2012 [accessed: July 15, 2019].

[6] Sinkó J. Clinical aspects of severe infections caused by antibioticresistant Gram-negative bacteria. The Empire strikes back? [Antibiotikumokkal szemben ellenálló Gram-negatív baktériumok okozta súlyos fertôzések a klinikus szemével. A Birodalom visszavág?] Orv Hetil. 2017; 158: 1528-1534. [Hungarian]

[7] Juhász E, Iván M, Pongrácz J, et al. Uncommon non-fermenting Gram-negative rods as pathogens of lower respiratory tract infection. [Ritkábban előforduló, alsó légúti fertőzést okozó Gramnegatív nem fermentáló pálcák.] Orv Hetil. 2018; 159: 23-30. [Hungarian]

[8] Illés D, Urbán E, Lázár A, et al. Changes in antibiotic resistance in cholangitis. Our clinical experience. [Az antibiotikumrezisztencia változása cholangitisben. Klinikai tapasztalataink.] Orv Hetil. 2019; 160: 1437-1442. [Hungarian]

[9] Gajdács M. Resistance trends and epidemiology of Aeromonas and Plesiomonas infections (RETEPAPI): a 10-year retrospective survey. Infect Dis (London). 2019; 51: 710-713.

[10] Matuz M, Benkő R, Hajdú E, et al. Evaluation of ambulatory antibiotic use in Hungary using drug-specific quality indicators (1996-2010). [A hazai ambuláns antibiotikum-alkalmazás minőségi indikátorok szerinti értékelése (1996-2010)]. Orv Hetil. 2013; 154: 947-956. [Hungarian]

[11] Acar JF, Goldstein FW. Trends in bacterial resistance to fluoroquinolones. Clin Inf Dis. 1997; 24(Suppl 1): S67-S73.

[12] Gajdács M, Ábrók M, Lázár A, et al. Comparative epidemiology and resistance trends of common urinary pathogens in a Tertiary-Care Hospital: a 10-year surveillance study. Medicina (Kaunas) $2019 ; 55: 356$.
[13] Cecchini M, Langer J, Slawomirski L. Antimicrobial resistance in G7 countries and beyond: economic issues, policies and options for action. OECD 2015; pp. 1-75. Available from: https:// www.oecd.org/els/health-systems/Antimicrobial-Resistancein-G7-Countries-and-Beyond.pdf [accessed: July 15, 2019].

[14] Adriaenssens N, Coenen S, Tonkin-Crine S, et al. European Surveillance of Antimicrobial Consumption (ESAC): disease-specific quality indicators for outpatient antibiotic prescribing. BMJ Qual Saf. 2010; 20: 764-772.

[15] Szabó A, Gajdács M, Balog EP, et al. Evaluation of public knowledge and attitudes towards antibiotic use in Hungary. 18th Danube-Kris-Mures-Tisa (DKMT) Euroregional Conference on Environment and Health, Book of Abstracts, 2016; p. 66.

[16] World Economic Forum. Global Risks. Eighth Edition. WEF, Cologny, 2013; pp. 28-33. Available from: http://www3.weforum.org/docs/WEF_GlobalRisks_Report_2013.pdf [accessed: July 15,2019$]$.

[17] World Health Organization. Global priority list of antibiotic-resistant bacteria to guide research, discovery, and development of new antibiotics. WHO, Geneva, 2017; pp. 1-7. Available from: http://www.who.int/medicines/publications/WHO-PPLShort_Summary_25Feb-ET_NM_WHO.pdf?ua=1 [accessed: July 15,2019$]$.

[18] Gajdács M. The concept of an ideal antibiotic: implications for drug design. Molecules 2019; 24: 892.

[19] Lee CR, Cho IH, Jeong BC, et al. Strategies to minimize antibiotic resistance. Int J Environ Res Public Health 2013; 10: 42744305 .

[20] Llor C, Bjerrum L. Antimicrobial resistance: risk associated with antibiotic overuse and initiatives to reduce the problem. Ther Adv Drug Saf. 2014; 5: 229-241.

[21] Davey P, Pagliari C, Hayes A. The patient's role in the spread and control of bacterial resistance to antibiotics. Clin Microbiol Infect. 2002; 8(Suppl 2): 43-68.

[22] Baadani AM, Baig K, Alfahad WA, et al. Physicians's knowledge, perceptions, and attitudes toward antimicrobial prescribing in Riyadh, Saudi Arabia. Saudi Med J. 2015; 36: 613-619.

[23] Chandan NG, Nagabushan H. Assessment of knowledge attitude and practice of interns towards antibiotic resistance and its prescription in a teaching hospital: a cross sectional study. Int J Basic Clin Pharmacol. 2016; 5: 442-446.

[24] Fehér Á. The practice of prescribing antibiotics among GPs in 2014. [Az antibiotikumok felírásának gyakorlata a háziorvosok körében 2014-ben.] EpInfo 2016; 23: 537-541. Available from: http://epa.oszk.hu/00300/00398/00705/pdf/EPA00398_ epinfo_2016_44.pdf [accessed: July 15, 2019]. [Hungarian]

[25] Magiorakos AP, Srinivasan A, Carey RB, et al. Multidrug-resistant, extensively drug-resistant and pandrug-resistant bacteria: an international expert proposal for interim standard definitions for acquired resistance. Clin Microbiol Infect. 2012; 18: 268-281.

[26] Marshall BM, Levy SB. Food animals and antimicrobials: impact on human health. Clin Microbiol Rev. 2011; 24: 718-733.

[27] Simpson SA, Wood F, Butler CC. General practitioners' perceptions of antimicrobial resistance: a qualitative study. J Antimicrob Chemother. 2007, 59: 292-296.

[28] Minen MT, Duquaine D, Marx MA, et al. A survey of knowledge, attitudes, and beliefs of medical students concerning antimicrobial use and resistance. Microb Drug Resist. 2010; 16: 285-289.

[29] Weller TM, Jamieson CE. The expanding role of the antibiotic pharmacist. J Antimicrob Chemother. 2004, 54: 295-298.

[30] Muñoz EB, Dorado MF, Guerrero JE, et al. The effect of an educational intervention to improve patient antibiotic adherence during dispensing in a community pharmacy. Aten Primaria 2014; 46: 367-375.

[31] Gajdács M, Paulik E, Szabó A. The opinions of community pharmacists related to antibiotic use and resistance. [Közforgalomban dolgozó gyógyszerészek antibiotikum felhasználással és rezisz- 
tenciával kapcsolatos véleménye.] Acta Pharm Hung. 2018; 88: 249-252. [Hungarian]

[32] Howard J, Sparrow N, Turnbull CJ, et al. Continuing professional development and revalidation: an analysis of general practitioners' recorded learning. Educ Prim Care 2009; 20: 298303.

[33] Paulik E, Bóka F, Kertész A, et al. Determinants of health-promoting lifestyle behaviour in the rural areas of Hungary. Health Promot Int. 2010, 25: 277-288.

[34] Nédó E, Paulik E. Association of smoking, physical activity, and dietary habits with socioeconomic variables: a cross-sectional study in adults on both sides of the Hungarian-Romanian border. BMC Public Health 2012, 12: 60.
[35] Fehér Á, Fekete M, Varga JT, et al. Medical students' knowledge on vaccinology. [Az orvostanhallgatók vakcinológiai tájékozottsága.] Orv Hetil. 2019; 160: 1193-1199. [Hungarian]

[36] WHO competency framework for health workers' education and training on antimicrobial resistance. World Health Organization, Geneva, 2018 (WHO/HIS/HWF/AMR/2018.1). Licence: CC BY-NC-SA 3.0 IGO. Available from: https://www.who. int/hrh/resources/WHO-HIS-HWF-AMR-2018.1/en/ [accessed: July 15, 2019]

(Gajdács Márió dr., Szeged, Eötvös u. 6., 6720 e-mail: gajdacs.mario@med.u-szeged.hu)

A Semmelweis Egyetem Általános Orvostudományi Kara örömmel tesz eleget annak a hagyománynak, hogy volt diákjait jubileumi díszoklevéllel tünteti ki.

Kérjük ezért azokat az orvosokat, akik diplomájukat az egyetem jogelődjénél, a BUDAPESTI KIRÁLYI MAGYAR PÁZMÁNY PÉTER TUDOMÁNYEGYETEMEN, a PÁZMÁNY PÉTER TUDOMÁNYEGYETEMEN, a BUDAPESTI ORVOSTUDOMÁNYI EGYETEMEN, illetVe a SEMMELWEIS ORVOSTUDOMÁNYI EGYETEMEN
1945-ben
1950-ben
1955-ben
1960-ben
1970-ben

szerezték meg, és szakterületükön legalább 30 évig dolgoztak, nyújtsák be kérelmüket a platina, rubin, vas, gyémánt, illetve arany díszoklevél elnyerése érdekében 2020. április 30-ig, a következő címre, az alábbi jelentkezési lapon.

\section{Semmelweis Egyetem Általános - Orvostudományi Kar \\ Dékáni Hivatal \\ 1085 Budapest, Üllői út 26. vagy 1428 Budapest Pf. 2}

A jubileumi díszoklevelek átadására elöreláthatóan októberben kerül sor. A pontos időpontról meghívó útján küldünk értesítést.

\section{JELENTKEZÉSI LAP}

arany, gyémánt, vas, rubin és platina díszoklevélhez

NÉV

(névváltoztatás feltüntetésével)

Születési idő:

Diploma kelte:

Lakcím:

Telefonszám:

E-mail cím:

Utolsó munkahely:

Rövid szakmai önéletrajz:

Aláirásommal hozzájárulok ahhoz, hogy fenti adataimat - az ALUMNI tevékenységgel összefüggésben - a SEMMELWEIS ALUMNI Iroda kezelje.

Dátum:

\section{kérelmező aláírása}

Aláirásommal hozzájárulok ahhoz, hogy a lakóhelyem szerinti illetékes önkormányzat megkeresésére, kerületi ünnepségre történő meghivás céljából az elérhetőségeim kiadásra kerüljenek.

A megfelelő válasz aláhúzandó. IGEN NEM

A cikk a Creative Commons Attribution 4.0 International License (https://creativecommons.org/licenses/by/4.0/) feltételei szerint publikált Open Access közlemény, melynek szellemében a cikk bármilyen médiumban szabadon felhasználható, megosztható és újraközölhetö, feltéve, hogy az eredeti szerző és a közlés helye, illetve a CC License linkje és az esetlegesen végrehajtott módositások feltüntetésre kerülnek. (SID_1) 